\title{
Editorial
}

\section{Thrombosis Research: Tradition and Translation}

\author{
Rüdiger E. Scharf ${ }^{1}$ \\ ${ }^{1}$ Division of Experimental and Clinical Hemostasis, Hemotherapy \\ and Transfusion Medicine, and Hemophilia Comprehensive Care \\ Center, Institute of Transplantation Diagnostics and Cell \\ Therapy, Heinrich Heine University Medical Center, Düsseldorf, \\ Germany
}

Hämostaseologie 2019;39:105-106.

The current issue of Hämostaseologie-Progress in Haemostasis is dedicated to the memory of Professor Gustav V.R. Born who died in 2018 at the age of 96 . His life, scientific career, achievements and unique personality are appreciated in a special article. ${ }^{1}$ Gustav Born's name will be inseparably linked to turbidimetric light transmission aggregometry of blood platelets, a technique that he introduced some six decades ago. ${ }^{2}$ Since then, with more than 5,650 citations, his Nature paper from 1962 has been one of the most cited articles ever published (Science Citation Index).

Born made a relevant prospective suggestion in the 1962 Nature paper: 'If it can be shown that ADP takes part in the aggregation of platelets in blood vessels, it is conceivable that AMP or some other substance could be used to inhibit or reverse platelet aggregation in thrombosis'. Indeed, inhibition of platelet function turned out to be the most important discovery made with optical aggregometry. In fact, this technique helped in establishing the option of preventing and treating arterial thrombosis by administration of antiplatelet agents. ${ }^{3}$ The beneficial use of antiplatelet agents against myocardial infarction and stroke would have been unconceivable without monitoring by platelet aggregometry. ${ }^{4}$

Thus, Gustav Born was a pioneer in platelet research and set standards to explore platelet biology, pathology and pharmacology. He also established several animal models, and by applying this experimental approach, he became a promoter of translational research to address clinical needs and to advance medical progress.
Translational research in thrombosis and haemostasis is also in the focus of this edition that was designed and managed by Professor Wolfram Ruf, Scientific Director of the Center for Thrombosis and Hemostasis (CTH) in Mainz. Under his guest editorship, eight review articles written by staff members and junior investigators were selected for this theme issue.

The contributions introduced by Ruf's editorial also reflect the broad spectrum of research activities and recent accomplishments at the $\mathrm{CTH} .^{5}$ Apart from these scientific communications, it will be of interest to our readers to learn more about the conceptual structure, objectives, future directions and interdisciplinary interactions that are ongoing at the Mainz Center. I am grateful to the authors and, specifically, to Wolfram Ruf for his effort and input to realize this edition of Hämostaseologie-Progress in Haemostasis.

As previously announced, ${ }^{6}$ at the GTH Congress 2019, a change in the Journal's Editorial Board was performed. Several Section Editors have completed their term or had asked to step down to be relieved of the editorial task. We now bid farewell to Paul Kyrle, Wien, Bernhard Lämmle, Bern/Mainz, Johannes Oldenburg, Bonn, Thomas Renné, Hamburg, Reinhard Schneppenheim, Hamburg, and Ulrich Walter, Mainz. We extend sincere thanks to them for their time-consuming dedication, professional comments and reliable recommendations, which helped the Journal in reviewing and selecting the most suitable articles for publication.

In accord with the GTH Council, current Editorial Board members and the publisher, several D-A-CH colleagues have been invited to join the Editorial Board and become Section Editors. Most of them have already been serving for the
Address for correspondence Univ.-Prof. Dr. Rüdiger E. Scharf, FAHA, Division of Experimental and Clinical Hemostasis, Hemotherapy and Transfusion Medicine, and Hemophilia Comprehensive Care Center, Institute of Transplantation Diagnostics and Cell Therapy, Heinrich Heine University Medical Center, Düsseldorf, Germany (e-mail: rscharf@uni-duesseldorf.de). (c) 2019 Georg Thieme Verlag KG

Stuttgart · New York

received

April 17, 2019

accepted

April 17, 2019
DOI https://doi.org/

10.1055/s-0039-1688782.

ISSN 0720-9355. 
Journal as members of our Advisory Board. We are giving a warm welcome to Lorenzo Alberio, Lausanne, Kerstin Jurk, Mainz, Robert Klamroth, Berlin, Paul Knöbl, Wien, Johanna Kremer-Hovinga, Bern, and Christoph Male, Wien. Specifically, we are delighted that all of them accepted our invitation and look forward to fruitful collaboration.

To address the needs of young investigators and to increase the Journal's attractiveness, we now have implemented the position of a Junior Editorial Board Member. We are pleased that Dr. Stefano Barco, Mainz, has accepted the invitation to take this place. The young scientific community in our field is asked to approach him directly with new suggestions, issues or concerns of any kind.

A warm thank you also goes to our Advisory Board members who have supported the Section Editors for several years and now finish their term. We say farewell to Monika Barthels, Hannover, Meinrad Gawaz, Tübingen, Viola HachWunderle, Frankfurt, Kurt Huber, Wien, Lázló Muszbek, Debrecen, Inge Scharrer, Frankfurt/Mainz, Ute Scholz, Leipzig, Verena Schröder, Bern, and Johann Wojta, Wien. Your support has been appreciated throughout.

As new Advisory Board members, Cihan Ay, Wien, Tamam Bakchoul, Tübingen, Jürg Hans Beer, Baden/Zürich, Jan Beyer-Westendorf, Dresden, Maria Brehm, Hamburg, Daniel Dürschmied, Freiburg, Tobias Fuchs, Hamburg,
Katharina Holstein, Hamburg, Berend Isermann, Magdeburg/Leipzig, Christoph Königs, Frankfurt, Harald Langer, Lübeck, Birgit Linnemann, Regensburg, Michael Nagler, Bern, Christoph Reinhardt, Mainz, Christoph Sucker, Berlin, Thomas Thiele, Greifswald, and Sacha Zeerleder, Bern, have been invited. Welcome on board of the Journal!

Conflict of Interest

None declared.

\section{References}

1 Scharf RE. The prominent pioneering 'plateleteer': reflections on and personal reminiscences of Gustav Victor Rudolf Born (1921-2018). Hamostaseologie 2019;39:107-114

2 Born GVR. Aggregation of blood platelets by adenosine diphosphate and its reversal. Nature 1962;194:927-929

3 Born GVR. Light on platelets. J Physiol 2005;568(Pt 3):713-714

4 Coller BS. Foreword: a brief history of ideas about platelets in health and disease. In: Michelson AD, Cattaneo M, Frelinger AL, Newman PJ, eds. Platelets. 4th ed. London - San Diego - Cambridge, MA: Academic Press Elsevier Inc.; 2019:xv-xxxviii

5 Ruf W. Translational research in thrombosis and hemostasis. Hamostaseologie 2019;39(01):115-116

6 Scharf RE. Changes and challenges. Hamostaseologie 2019;39 (01):1-3 